\title{
THE ANTI-INFLAMMATORY ACTIVITY OF BORON DERIVATIVES IN RODENTS
}

\author{
Iris H. Hall', Bruce S. Burnham 1, Shang Y. Chen1, Anup Sood², \\ Bernard F. Spielvogel2 and Karen W. Morse ${ }^{3}$ \\ 1 Division of Medicinal Chemistry and Natural Products, School of Pharmacy, \\ University of North Carolina, Chapel Hill, North Carolina 27599-7360, USA \\ 2 Boron Biologicals, Inc., 620 Hutton Street,Raleigh, North Carolina 27606, USA \\ 3 Department of Chemistry and Biochemistry, Utah State University, Logan, Utah 84322, USA
}

\begin{abstract}
Acyclic amine-carboxyboranes were effective anti-inflammatory agents in mice at $8 \mathrm{mg} / \mathrm{kg} \times 2$. These amine-carboxyboranes were more effective than the standard indomethacin at $8 \mathrm{mg} / \mathrm{kg} x$ 2, pentoxifylline at $50 \mathrm{mg} / \mathrm{kg} \times 2$, and phenylbutazone at $50 \mathrm{mg} / \mathrm{kg} \times 2$. The heterocyclic amine derivatives as well as amine-carbamoylboranes, carboalkoxyboranes, and cyanoboranes were generally less active. However, selected aminomethyl-phosphonate- $\mathrm{N}$-cyanoboranes demonstrated greater than $60 \%$ reduction of induced inflammation. The boron compounds were also active in the rat induced edema, chronic arthritis, and pleurisy screens, demonstrating activity similar to the standard indomethacin. The compounds were effective in reducing local pain and decreased the tail flick reflex to pain. The derivatives which demonstrated good antiinflammatory activity were effective inhibitors of hydrolytic lysosomal, and proteolytic enzyme activities with $1 C_{50}$ values equal to ${ }^{-6}-6 \mathrm{M}$ in mouse macrophages, human leukocytes, and $\mathrm{Be}$ Sal osteofibrolytic cells. In these same cell lines, the agents blocked prostaglandin cyclooxygenase activity with $1 C_{50}$ values of $10^{-6} \mathrm{M}$. In mouse macrophage and human leukocytes, $5^{\prime}$ lipoxygenase activity was also inhibited by the boron derivatives with $\mathrm{IC}_{50}$ values of $10^{-6} \mathrm{M}$. These $1 \mathrm{C}_{50}$ values for inhibition of these enzyme activities are consistent with published values of known anti-inflammatory agents which target these enzymes.
\end{abstract}

\section{INTRODUCTION}

Amine-cyanoboranes and amine-carboxyboranes have previously been shown to inhibit induced inflammation in rodents at $10 \mathrm{mg} / \mathrm{kg}^{1}$. These studies were expanded to include di- and tripeptides containing boron ${ }^{2}$, tricyclohexyl- and triphenylphosphine- boranes, carboxyboranes and cyanoboranes ${ }^{3}$, and boronated 2'-deoxynucleosides ${ }^{4}$ which demonstrated anti-inflammatory activity in mice. These boron compounds were potent inhibitors of lysosomal hydrolytic enzyme activities and their release from $C_{1}$-mouse hepatic tissue and human PMNs ${ }^{1}$. The current study extends this investigation to other boron derivatives and additional inflammatory disease models other than induced edema. Selective derivatives of individual chemical classes of boron compounds are examined for their mode of action using isolated enzymes and tissue cultured cells to determine their effects on hydrolytic and proteolytic enzymes and regulatory enzymes of the prostaglandin and leukotriene synthetic pathways. 


\section{METHODS AND MATERIALS}

\section{Source of Materials}

All of the boron derivatives have previously been synthesized and the literature references $5-24$ for each compound are listed in Table 1. The chemical and physical characteristics were identical to those reported in the literature. Test compounds (1-94) were homogenized in $0.05 \%$ tween 80-distilled/ $\mathrm{H}_{2} \mathrm{O}$.

Anti-inflammatory Activity. $\quad \mathrm{CF}_{1}$ male mice $(\sim 25 \mathrm{~g})$ were administered test drugs $(1-94)$ at 8 $\mathrm{mg} / \mathrm{kg} /$ day in $0.05 \%$ Tween $80 / \mathrm{H}_{2} \mathrm{O}$ intraperitoneally at $3 \mathrm{~h}$ and again at $30 \mathrm{~min}$ prior to the injection of $0.2 \mathrm{ml}$ of $10 \%$ carrageenan in $0.9 \%$ saline into the plantar surface of the right hind foot. Saline was injected into the left hind foot which served as the standard base line. After $3 \mathrm{~h}$, both feet were excised at the tibiotarsal (ankle) joint according to the modified method of Winter 25,26 , resulting in an $84 \mathrm{mg}$ increase in the paw weight of the control mice. Selected compounds $2,4,5,6,8,9,11,12,15,16,23,33,34,36,46,48,74,76$, and 78 were tested in Sprague Dawley male rats $(\sim 350 \mathrm{~g})$ at $8 \mathrm{mg} / \mathrm{kg} \times 2$, I.P. The average paw weight of the control rats was increased $1.732 \mathrm{~g}$ by the inflammation agent.

Local Analgesic Screen. Male $\mathrm{CF}_{1}$ mice $(\sim 25 \mathrm{~g})$ were administered selected test drugs $(1-89)$ at $8 \mathrm{mg} / \mathrm{kg}$, I.P. $20 \mathrm{~min}$ prior to the administration of $0.5 \mathrm{ml} \mathrm{of} 0.6 \%$ acetic acid, I.P. After $5 \mathrm{~min}$, the number of stretches, characterized by repeated contractions of the abdominal musculature, accompanied by the extension of the hind limbs, were counted for the next $10 \min ^{25}$. The control mice afforded 61 stretch reflexes per $10 \mathrm{~min}$.

Hot Plate Tail Flick Screen. CF 1 male mice $(\sim 28 \mathrm{~g})$ were administered agents at $8 \mathrm{mg} / \mathrm{kg}, \mathrm{I} . \mathrm{P} .15$ min prior to placement on a hot plate maintained at $100^{\circ} \mathrm{C}$. The time elapse for the tail to be raised was determined using a digital read-out connected to the hot plate 27 . Tail flick responses of mice injected with morphine was used as a standard.

Anti-pleurisy Screen. Sprague Dawley male rats $(280 \mathrm{~g})$ were administered test drugs $2,8,9$, $12,15,16,20,34$, or 76 at $8 \mathrm{mg} / \mathrm{kg}$ I.P., $1 \mathrm{~h}$ before and $3 \mathrm{~h}$ after injecting into the pleural cavity $0.05 \mathrm{mi}$ of a $0.316 \%$ Evan's blue and carrageenan 28 . Six hours later, the rats were sacrificed and the fluid collected from the pleural cavity. Control rats produced an average of $2.15 \mathrm{ml}$ of fluid.

Chronic Adjuvant Arthritic Screen. Male Sprague Dawley rats $(\sim 180 \mathrm{~g})$ were injected at the base of the tail with $0.2 \mathrm{ml}$ of solution containing $100 \mathrm{mg}$ of dried $\mathrm{M}$. butyricum and $40 \mathrm{mg}$ digitonin in $20 \mathrm{ml}$ of light mineral oil 29 . Test drugs $2,7,8,12,20,34$, or 78 were administered on Day 3 to Day 21 at $8 \mathrm{mg} / \mathrm{kg} /$ day, I.P. The following day, the rats were sacrificed and the feet were excised and weighed. Control rats averaged a $0.750 \mathrm{~g}$ net weight increase.

Cell Maintenance of Cultured Cells. Mouse macrophages J774A were maintained in Dulbecco's modified Eagle medium (DMEM) + 15\% FCS + P/S. RMPI 1788 human leukocytes were maintained in RMPI $1640+10 \% \mathrm{FCS}+\mathrm{P} / \mathrm{S}$. Be Sal human osteo-fibrolytic cells were maintained in RMPI $+10 \%$ FCS + P/S. Rat osteogenic sarcoma cells UMR-106 were maintained in DMEM + $10 \%$ FCS + P/S.

Lysosomal Hydrolytic Enzymatic Activities. Acid phosphatase, aryl sulphatase, cathepsin, and trypsin proteolytic activities were measured utilizing human Be Sal osteo-fibrolytic osteoporosis cells, leukocytes, or mouse macrophages $\mathrm{J} 774\left(1 \times 10^{6}\right.$ cells). Drugs were incubated from $10^{-8}$ to $10^{-3} \mathrm{M}$ for $30 \mathrm{~min}$ at $37^{\circ} \mathrm{C}$. Acid phosphatase activity was determined using $0.1 \mathrm{M} \beta-$ glycerolphosphate in $0.1 \mathrm{M}$ acetate buffer at $\mathrm{pH} 5.0^{32}$. The reaction was stopped with $10 \% \mathrm{TCA}$ and centrifuged at $3000 \mathrm{~g} \times 6 \mathrm{~min}$. The supernatant inorganic phosphate was determined by the spectrophotometric method of Chen et. al. ${ }^{30}$. The net inorganic phosphate released in $30 \mathrm{~min}$ 
was corrected by subtracting the blank test. Aryl sulphatase activity was measured using 0.72 mmole of p-nitrocatechol sulfate as a substrate in $0.2 \mathrm{M}$ acetate buffer, $\mathrm{pH} 5.0$ for $30 \mathrm{~min}$ at $37^{\circ}$ $c^{31}$. The reaction was terminated with $4 \mathrm{~N} \mathrm{NaOH}$. The formation of 4-nitrocatechol in the supernatant was measured spectrophotometrically at $510 \mathrm{~nm}$ and corrected for blank values. Cathepsin activity was determined using $2 \%$ azocasien as the substrate in $0.1 \mathrm{M}$ acetate buffer, $\mathrm{pH} 5.0$ for $30 \mathrm{~min}$ at $37^{\circ} \mathrm{C}{ }^{31}$. The reaction was terminated with $10 \%$ TCA and centrifuged. The supernatant was assayed for acid-soluble peptide fragments at $366 \mathrm{~nm}$ and corrected for blank values.

Proteolytic Enzyme Activities. Trypsin proteolytic activity was determined by the method of Schleuning and Fritz ${ }^{33}$ using $2.0 \mathrm{ml}$ of $0.1 \mathrm{M}$ Tris buffer, $\mathrm{pH} 8.0$ and $6 \mathrm{mM}$ of N-benzoyl-Larginine ethyl ester (BAEE) substrate. The hydrolysis of BAEE over a $30 \mathrm{~min}$ period was determined at $253 \mathrm{~nm}$ and blank values were subtracted ${ }^{33}$. Elastase activity was determined by the method of Kleinerman et al. ${ }^{34}$ using $2.9 \mathrm{ml}$ of $0.2 \mathrm{M}$ Tris- $\mathrm{HCl}$ buffer, $\mathrm{pH} \mathrm{8.0,2}$ units $(200 \mu \mathrm{l})$ of porcine pancreatic elastase (Sigma, Type III) and $20 \mu \mathrm{l} \mathrm{N}$-succinyl-L-alanyl-L-alanine-pnitroanilide (Sigma, $100 \mathrm{mg}$ in $5 \mathrm{ml}$ of methyl-2-pyrrolidone). The cleaved product p-nitroanilide was determined at $410 \mathrm{~nm}$ for a 3 min period. Collagenase activity was determined at $410 \mathrm{~nm}$ for a $3 \mathrm{~min}$ period. Collagenase activity was determined by the method of $\mathrm{Hu}$ et al. $35 \mathrm{using} 1 \mathrm{ml}$ of $50 \mathrm{mM}$ Tris $+5 \mathrm{mM} \mathrm{CaCl} 2$ buffer, $\mathrm{pH} 7.6,10 \mu \mathrm{g} 3 \mathrm{H}$-collagen $\mathrm{N}$-(propionate 2,3$\left.{ }^{3} \mathrm{H}\right)$ propionylated $(0.51 \mathrm{mCi} / \mathrm{mg})$ and $10 \mu \mathrm{g}$ collagenase (Sigma, Type III Clostridium histolyticum $)^{36}$ incubated for $24 \mathrm{~h}$ at $37^{\circ} \mathrm{C}$. The reaction was stopped with $1 \mathrm{ml} 50 \mathrm{mM}$ EDTA. The tubes were then centrifuged at $10,000 \mathrm{~g}$ for $15 \mathrm{~min}$. The supernatant was counted (Packard Tricarb liquid scintillation counter). Background radioactivity values were subtracted from each sample and corrected for quenching.

Prostaglandin Synthetase Activity. The incubation medium of Tomlinson et al. ${ }^{37}$ was used to determine prostaglandin formation et al. from ${ }^{3} \mathrm{H}(\mathrm{N})$-arachidonic acid $(100 \mathrm{Ci} / \mathrm{mmole})$ and $10 \mathrm{mg}$ of purified commercial prostaglandin synthetase from bovine seminal vesicles (Miles Research Products) or $10^{6} \mathrm{~J} 774$ macrophage cells. After $1 \mathrm{~h}$, the reaction was terminated with $2 \mathrm{~N} \mathrm{HCl}$ and the mixture was extracted with ether and evaporated. The residue was dissolved in ethyl acetate and spotted on silica gel TLC plates which were eluted with chloroform, methanol, water, and acetic acid (90:8:1:0.8). The plates were developed in iodine vapor and the area appropriate to prostaglandin standards was scraped and counted ${ }^{38}$, i.e. arachidonic acid, $\mathrm{PgA}_{2}, \mathrm{PgE}_{2}$, and $\mathrm{PgF}_{2} \alpha$. The dpm in each area was calculated as percent of the total dpm on the tlc plate.

5'Lipoxygenase Activity. Mouse macrophages or human leukocytes $\left(5 \times 10^{6}\right.$ cells) were maintained as described above and then incubated at $10^{-4}$ to $10^{-8} \mathrm{M}$. The cells were harvested by centrifugation and incubated in a phosphate buffer, $\mathrm{pH} 7.2,+0.6 \mathrm{mM} \mathrm{CaCl}_{2}+1.0 \mathrm{mM} \mathrm{MgCl}_{2}$, the calcium ionophore $\mathrm{A} \mathrm{23187}$, and $3 \mathrm{H}$-arachidonic acid. After $20 \mathrm{~min}$ incubation at $37^{\circ} \mathrm{C}$, EtOAc: $\mathrm{CH}_{2} \mathrm{Cl}_{2}$ (2:3) supplemented with $12 \mathrm{mg}$ arachidonic acid was added. The organic phase was extracted and dried. The residue was taken up in ethyl acetate and $100 \mu \mathrm{L}$ was plated on silica gel TLC plates eluted with methylene chloride:methanol:acetic acid: water (90:8:1:0.8). The plates were scaped in the area that corresponded to 5-HETE and counted $39-40$. The $1 C_{50}$ values were calculated for the compounds.

In Table 1 , the anti-inflammatory activity is represented as percentage of control and the standard deviation $\left(X \pm S\right.$.D.). $N$ equals the number of animals used in each test group. $I_{50}$ values were calculated as the dose $(\mathrm{log})$ which afforded $50 \%$ inhibition of the enzyme activity \pm S.D. The $P$ values were determined using the Student's " $t$ " test and analysis of variance. 


\section{RESULTS}

In the mouse edema screen, compounds. 15, 16, and 19, the methyl and ethyl ester derivatives of amine-carboxyboranes 13-20 were less active than the simple acids (Table 1 ). The amides 21-31, except compound 23, were also less active than the acids. The ammonia di- and trimethylamine cyanoboranes $32-34$ demonstrated good activity as did the $\mathrm{C}_{18} \mathrm{H}_{37}$ derivative 36 and the dicyano derivative 40 . Nevertheless, the remaining cyanoboranes demonstrated minimum activity. The phosphonoacetate analogs and aminoalkylphosphonate derivatives demonstrated good activity where compounds $54,62,64,66,67,68,69,71,73,74,75$, and 76 caused at least $40 \%$ reduction of induced edema in mice at $8 \mathrm{mg} / \mathrm{kg} \times 2$. The heterocyclic amine boranes derivatives 78-94 were not as active as other boron containing derivatives. Compound 78 caused $45 \%$ reduction of induced edema. Compounds $83,84,87$, and 91 resulted in at least $30 \%$ reduction of inflammation in mice.

Compounds $4,5,6,8,15$, and 23 demonstrated at least $40 \%$ reduction in induced edema in rats at $8 \mathrm{mg} / \mathrm{kg} \times 2$ (Table 2). Chronic arthritis in rats was reduced significantly by 7,20 , and 34 with greater than $75 \%$ reduction of pannus at $8 \mathrm{mg} / \mathrm{kg} / \mathrm{day}$. Compounds $2,8,12$, and 78 were significantly active in this screen. Pleurisy edema in rats was reduced significantly by compounds $2,8,9,12,16,20,34$, and 76 . Selective agents were able to block local pain induced by acetic acid in mice. Compounds $1,4,5,8,9,12,15,16,33,34,35$, and 78 reduced the reflex action by $80 \%$. Compounds $2,7,20,23,27,36,46,48,74,75,76$, and 77 caused at least $45 \%$ reduction of the reflex action. The tail flick assay time was increased by compounds 2 , $3,5,8,9,12,15,16,46,75$, and 76 ; however, only compounds 9,75 , and 76 were as effective as morphine in blocking central pain.

Lysosomal enzyme activity, e.g. acid phosphatase, cathepsin, and aryl sulfatase activities (Table 3) were inhibited by the boron derivatives. Acid phosphatase activity in mouse macrophages demonstrated $\mathrm{IC}_{50}$ values between $0.90-7.72 \times 10^{-6} \mathrm{M}$ for the boron derivatives tested, for acid cathepsin activity values between $0.76-9.45 \times 10^{-6} \mathrm{M}$, and for aryl sulfatase activity values between 1.37-9.71 $10^{-6} \mathrm{M}$, except for compound $14\left(17.6 \times 10^{-6} \mathrm{M}\right)$. Human Be Sal cells showed $1 C_{50}$ values for acid phosphatase activity between $1.10-18.3 \times 10^{-6} \mathrm{M}$, for acid cathepsin activity values between $0.85-6.17 \times 10^{-6} \mathrm{M}$, and for aryl sulfatase activity values between $6.07-10.00 \times$ $10^{-6} \mathrm{M}$. For human leukocytes acid phosphatase activity, the $I C_{50}$ values (Table 4 ) were between $8.57-10.49 \times 10^{-6} \mathrm{M}$, and acid cathepsin activity values between $5.38-7.71 \times 10^{-6} \mathrm{M}$. Proteolytic enzyme activities were also reduced by the boron derivatives. Macrophage trypsin activity (Table 5 ) was inhibited with $I C_{50}$ values between $1.26-4.34 \times 10^{-6} \mathrm{M}$, macrophage elastase activity was inhibited with $I C_{50}$ values ranging from $0.22-9.01 \times 10^{-6} \mathrm{M}$. Be Sal trypsin activity demonstrated inhibition with $I_{50}$ values between $3.35-7.40 \times 10^{-6} \mathrm{M}$ (Table 4 ) whereas elastase activity was inhibited with $I C_{50}$ values in the range of $0.58-3.86 \times 10^{-6} \mathrm{M}$. Macrophage trypsin and elastase activities were inhibited by the compounds with $1 C_{50}$ values $\sim 10^{-6} \mathrm{M}$. Commercial collagenase $I$ activity was inhibited with $1 C_{50}$ values between $615-812 \times 10^{-6} \mathrm{M}$ (Table 5) and type II activity with $I_{50}$ values between $89-124 \times 10^{-6} \mathrm{M}$. Human bone osteogenic sarcoma cells (Table 6) trypsin activity was inhibited with $I C_{50}$ values of $5.67-10.51 \times 10^{-6} \mathrm{M}$, elastase activity values of $8.09-10.34 \times 10^{-6} \mathrm{M}$, and acid cathepsin activity values between 4.67$6.62 \times 10^{-6} \mathrm{M}$. Beef seminal vesicle prostaglandin cyclooxygenase activity (Table 7) was inhibited by the boron derivatives with $I C_{50}$ values ranging from $0.71-7.60 \times 10^{-6} \mathrm{M}$. Macrophage prostaglandin cyclooxygenase activity $I C_{50}$ values were between $1.47-7.72 \times 10^{-6} \mathrm{M}$, and Be Sal cells showed $\mathrm{IC}_{50}$ values between $1.09-8.04 \times 10^{-6} \mathrm{M}$. Human leukocyte 5 -lipoxygenase activity was inhibited by the boron derivatives with $\mathrm{IC}_{50}$ values between $3.47-6.43 \times 10^{-6} \mathrm{M}$. 


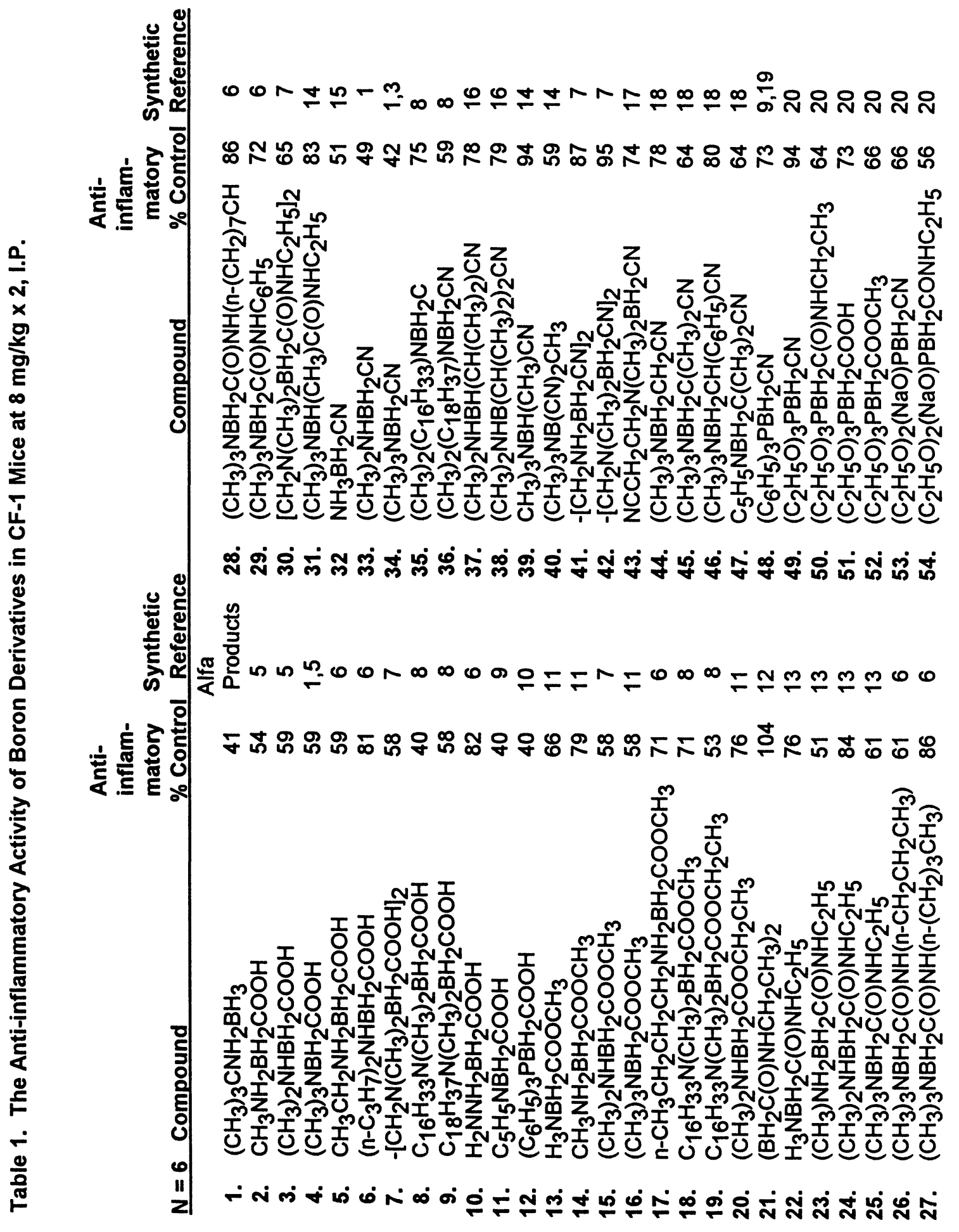




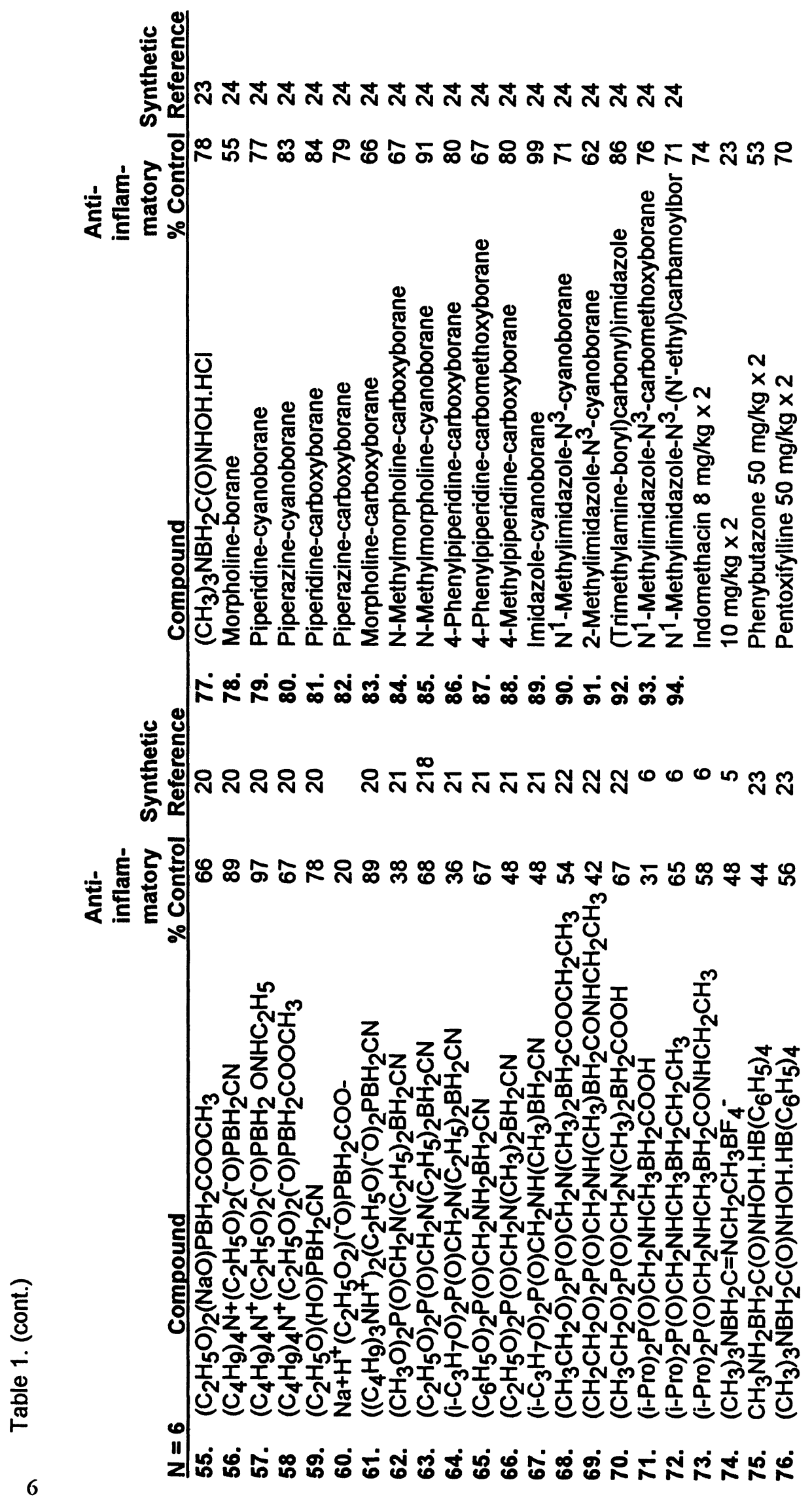


Table 2. The in vivo Antiinflammatory and Analgesic Activities of Boron Derivativesin Rats and Mice at $8 \mathrm{mg} / \mathrm{kg}(\%$ of control)

\begin{tabular}{|c|c|c|c|c|c|c|}
\hline \multirow[b]{2}{*}{ Compound } & \multicolumn{3}{|c|}{ Rat } & & \multicolumn{2}{|c|}{ Mice } \\
\hline & Inflammatory & $\begin{array}{l}\text { Chronic } \\
\text { Arthritis }\end{array}$ & Pleurisy & & $\begin{array}{c}\text { Writhing } \\
\text { Reflex }\end{array}$ & $\begin{array}{l}\text { Tail } \\
\text { Flick }\end{array}$ \\
\hline 1 & $-\cdots$ & -- & -- & & 19 & -- \\
\hline 2 & 70 & 53 & 61 & & 31 & 147 \\
\hline 3 & -- & -- & -- & & -- & 156 \\
\hline 4 & 55 & -- & - & & 2 & -- \\
\hline 5 & 59 & -- & -- & & 1 & 196 \\
\hline 6 & 55 & -- & -- & & 19 & -- \\
\hline 7 & -- & 24 & --- & & 55 & --- \\
\hline 8 & 59 & 40 & 19 & & 16 & 167 \\
\hline 9 & 72 & -- & 37 & & 14 & 231 \\
\hline 11 & 77 & --- & -- & & --- & -- \\
\hline 12 & 61 & 49 & 28 & & 19 & 197 \\
\hline 15 & 59 & -- & 86 & & 12 & 147 \\
\hline 16 & 71 & --- & 45 & & 2 & 180 \\
\hline 20 & --- & 13 & 61 & & 36 & -- \\
\hline 23 & 41 & -- & -- & & 27 & 81 \\
\hline 25 & --- & --- & --- & & 89 & -- \\
\hline 30 & --- & --- & --- & & 34 & --- \\
\hline 33 & 61 & --- & --- & & 15 & -- \\
\hline 34 & 65 & 4 & 65 & & 18 & --- \\
\hline 35 & -- & --- & --- & & 16 & -- \\
\hline 36 & 74 & --- & --- & & 61 & --- \\
\hline 46 & -- & --- & --- & & 46 & 191 \\
\hline 48 & 78 & -- & -- & & 50 & 134 \\
\hline 74 & 81 & --- & --- & & 40 & --- \\
\hline 75 & -- & --- & & --- & 34 & 279 \\
\hline 76 & 60 & -.- & 50 & & 45 & 258 \\
\hline 77 & --- & -- & --- & & 41 & 139 \\
\hline 78 & 83 & 33 & --. & & 15 & -.- \\
\hline 87 & -.- & --- & -- & & 89 & --- \\
\hline Indomethacin & 78 & 55 & 12 & & 43 & -- \\
\hline Morphine & & & & & & 213 \\
\hline Phenylbutazone & 47 & & & & & \\
\hline
\end{tabular}

Discussion

The amine-carboxyboranes and related derivatives were not all active as anti-inflammatory agents in rodents at $8 \mathrm{mg} / \mathrm{kg} \times 2$. Nevertheless, selected compounds were equally active as the clinically used standards indomethacin, phenylbutazone, and pentoxifylline which afforded 26 , 47 , and $30 \%$ inhibition, respectively of induced inflammation at their therapeutic dose. A number of the amine-carboxyboranes and cyanoborane derivatives were more potent in reducing edema at $8 \mathrm{mg} / \mathrm{kg} \times 2$. The mode of actions of the active compounds appears to be similar to those previously reported for cyanoboranes ${ }^{1}$ in that these agents effectively reduced the activities of lysosomal and proteolytic enzymes in a number of cultured cells. Particularly important is their inhibition on these processes in macrophages, leukocytes, and Be Sal osteo-fibrolytic cells. Studies have recently shown that the carboxyborane derivatives effectively inhibit the release of chemical mediators, e.g. tumor necrosis factor-alpha, II-1 and II-2 from macrophages and further, 
these same agents reduce the movement of PMNs and macrophages to sites of inflammation 41 . These chemical mediators, when released from inflammation cells, interact with high affinity receptors of target cells causing release of hydrolytic and proteolytic enzymes which cause local destruction of the tissue. Released locally also are prostaglandins and leukotrienes which afford additional inflammation, edema, pain, and destruction of tissue. Apparently, the boron derivatives are potent inhibitors of both prostaglandin cycooxygenase and 5'-lipoxygenase activities of human leukocytes and mouse macrophages with $I_{50}$ values which are typical of anti-inflammatory agents, i.e. $10^{-6} \mathrm{M}$. The fact that these agents are dual inhibitors is most significant since all agents are not able to achieve this function. The inhibition of 5 -lipoxygenase activity by the amine-carboxyboranes is potent achieving an order of magnitude greater inhibition than most dual inhibitors under investigation 41,42 . The amine-carboxyboranes, like most antiinflammatory agents, function by multiple modes of action to reduce inflammation and pain.

Table 3. $I_{50}$ Values $\times{ }^{10^{-6}} \mathrm{M}$ For Inhibition of Lysosomal Enzymes

\begin{tabular}{|c|c|c|c|c|c|c|}
\hline \multirow[b]{2}{*}{ Compound \# } & \multicolumn{3}{|c|}{$\begin{array}{l}\text { Mouse } \\
\text { Macrophage }\end{array}$} & \multicolumn{3}{|c|}{$\begin{array}{c}\text { Human } \\
\text { Be Sal Osteofibrolytic }\end{array}$} \\
\hline & $\begin{array}{c}\text { Acid } \\
\text { Phosphatase }\end{array}$ & Cathepsin & $\begin{array}{l}\text { Aryl } \\
\text { Sulfatase }\end{array}$ & $\begin{array}{c}\text { Acid } \\
\text { Phosphatase }\end{array}$ & Cathepsin & $\begin{array}{l}\text { Aryl } \\
\text { Sulfatase }\end{array}$ \\
\hline 1 & - & 8.08 & 4.62 & 10.20 & 4.28 & 9.14 \\
\hline 2 & 0.90 & 9.45 & 8.30 & & 1.77 & 8.86 \\
\hline 3 & 4.75 & 6.39 & & & & \\
\hline 7 & 3.32 & 8.37 & & & & \\
\hline 8 & 0.94 & 7.18 & 9.71 & 2.06 & 1.37 & 6.07 \\
\hline 9 & 5.34 & 5.09 & & & & \\
\hline 11 & & & & 18.30 & 5.44 & 8.16 \\
\hline 12 & 1.08 & 5.52 & 8.58 & 15.30 & 4.28 & 9.33 \\
\hline 15 & 1.04 & 6.71 & 7.41 & 1.10 & & 8.59 \\
\hline 16 & 3.55 & 8.28 & 17.60 & & 0.73 & \\
\hline 20 & 1.12 & 3.94 & 9.27 & & 1.28 & 7.62 \\
\hline 23 & 1.12 & 3.95 & 9.27 & 8.60 & 1.93 & 7.63 \\
\hline 33 & 1.13 & 5.54 & 9.02 & 8.70 & 0.85 & 7.91 \\
\hline 34 & 1.05 & 6.34 & 9.29 & 15.90 & 1.34 & 8.87 \\
\hline 35 & 0.33 & 4.97 & 7.16 & 2.01 & 10.00 & \\
\hline 36 & 2.68 & 3.69 & & & & \\
\hline 40 & 1.10 & 6.89 & 8.48 & & & \\
\hline 46 & 7.72 & 2.57 & 3.40 & & & \\
\hline 57 & 4.43 & 6.49 & & & & \\
\hline 59 & 2.04 & 6.55 & & & & \\
\hline 74 & 1.31 & 9.13 & 6.03 & & 6.17 & 8.80 \\
\hline 75 & 6.61 & 4.58 & 1.50 & & & \\
\hline 76 & 3.96 & 1.69 & 1.37 & & & \\
\hline 77 & 6.59 & 5.13 & 1.40 & & & \\
\hline 78 & 3.18 & 0.76 & & 10.30 & 4.40 & 8.99 \\
\hline 83 & 0.16 & 1.76 & 7.59 & & 2.93 & 8.99 \\
\hline 87 & 2.68 & 3.99 & & & & \\
\hline 95 & 3.24 & 9.24 & & & & \\
\hline
\end{tabular}


Table 4. $I C_{50}$ Values $\times 10^{-6} M$ For Inhibition of Human Enzyme Activities

\begin{tabular}{|c|c|c|c|c|c|}
\hline \multirow[b]{2}{*}{ Compound \# } & \multicolumn{2}{|c|}{ Be Sal Osteofibrolytic } & \multicolumn{3}{|c|}{ Leukocytes } \\
\hline & Trypsin & Elastase & Acid Phosphatase & Cathpsin & Trypsin \\
\hline 1 & 7.00 & 3.15 & & & \\
\hline 2 & 7.04 & 1.39 & -- & 7.03 & 8.50 \\
\hline 8 & 7.40 & 3.86 & -- & 6.46 & \\
\hline 12 & 5.70 & 1.96 & 7.25 & 11.00 & \\
\hline 15 & 6.14 & 1.31 & & & \\
\hline 16 & & & 9.94 & 5.97 & 6.72 \\
\hline 20 & 4.36 & 1.97 & & & \\
\hline 23 & 4.36 & 0.98 & 10.80 & 9.77 & \\
\hline 33 & 6.43 & 3.36 & 10.49 & 5.38 & 11.31 \\
\hline 34 & 3.98 & 3.29 & 10.03 & 7.71 & 9.95 \\
\hline 35 & 5.87 & 1.65 & & & \\
\hline 36 & & & 8.57 & & 7.25 \\
\hline 40 & 3.35 & 1.21 & 6.52 & 10.62 & \\
\hline 74 & 4.47 & 2.12 & 9.69 & & 9.68 \\
\hline 76 & 3.35 & 3.60 & & & \\
\hline 78 & 7.88 & 1.84 & 8.58 & 7.28 & 7.40 \\
\hline 83 & 7.88 & 0.575 & & & \\
\hline
\end{tabular}

Table 5. Proteolytic Activity $I C_{50}$ Values $\times 10^{-6} \mathrm{M}$ for Boron Derivatives

\begin{tabular}{|c|c|c|c|c|}
\hline \multirow[b]{2}{*}{ Compound \# } & \multicolumn{2}{|c|}{ Mouse Macrophage } & \multicolumn{2}{|c|}{ Clostridium histolyticum } \\
\hline & Trypsin & Elastase & Collagenase I & Collagenase II \\
\hline 1 & 2.09 & 0.22 & --- & 101 \\
\hline 2 & 2.34 & 2.32 & -- & 90 \\
\hline 3 & 3.10 & 2.67 & 667 & -- \\
\hline 7 & 2.33 & 2.76 & -- & -- \\
\hline 8 & 1.26 & 1.80 & 615 & 109 \\
\hline 9 & 2.07 & 6.29 & 663 & -- \\
\hline 12 & 1.77 & 3.04 & -- & 107 \\
\hline 15 & 2.78 & 2.14 & -- & -- \\
\hline 16 & 3.23 & 8.76 & 797 & 124 \\
\hline 20 & 2.02 & 3.28 & --- & --- \\
\hline 23 & 2.03 & 3.29 & -- & -- \\
\hline 33 & 2.44 & 2.53 & -- & 106 \\
\hline 34 & 1.41 & 1.35 & -- & 113 \\
\hline 35 & 2.69 & 2.75 & -- & -- \\
\hline 36 & 4.34 & 10.30 & 617 & -- \\
\hline 40 & 1.63 & 2.02 & -- & 110 \\
\hline 46 & 2.40 & 5.21 & --- & 101 \\
\hline 57 & 3.76 & 9.01 & 643 & -- \\
\hline 59 & 4.46 & 8.27 & -- & -.. \\
\hline 74 & 1.83 & 2.32 & --- & 97 \\
\hline 75 & 2.51 & 7.59 & --- & 89 \\
\hline 76 & 2.06 & 4.83 & --. & 99 \\
\hline 77 & 2.14 & 1.49 & -.. & 91 \\
\hline 78 & 2.39 & 5.94 & 687 & $\ldots$ \\
\hline 83 & 2.37 & 0.96 & -- & -.. \\
\hline 87 & 2.85 & 6.98 & 783 & 96 \\
\hline 95 & 2.62 & 6.17 & 812 & --- \\
\hline
\end{tabular}


Table 6. Rat UMR-106 Bone Osteosarcoma $I C_{50}$ Values $\times 10^{-6} \mathrm{M}$

\begin{tabular}{cccc} 
Compound & Trypsin & $\begin{array}{c}\text { Neutral } \\
\text { Cathepsin }\end{array}$ & Elastase \\
\hline 1 & 7.74 & 4.67 & 9.26 \\
2 & 9.89 & 5.82 & 8.94 \\
8 & 6.56 & 6.59 & 9.58 \\
12 & 5.67 & 5.81 & 8.86 \\
15 & 6.57 & 6.10 & 9.74 \\
20 & 9.18 & 6.62 & 10.34 \\
33 & 7.54 & 6.24 & 9.04 \\
34 & 2.62 & 5.46 & 8.99 \\
35 & 7.28 & 6.31 & 9.19 \\
40 & 9.48 & 6.54 & 9.96 \\
74 & 10.51 & 6.55 & 10.02 \\
83 & 9.89 & 5.41 & 8.09
\end{tabular}

Table 7. The Effects of Amine-carboxyboranes on Prostaglandin Cyclooxygenase and 5'Lipoxygenase Activities $I_{50}$ Values $\times 10^{-6} \mathrm{M}$

\begin{tabular}{|c|c|c|c|c|c|}
\hline \multirow[b]{2}{*}{ Compound \# } & \multicolumn{3}{|c|}{ Prostaglandin Cyclooxygenase } & \multicolumn{2}{|c|}{ 5'-lipoxygenase } \\
\hline & Macrophages & $\begin{array}{c}\text { Be Sal } \\
\text { Osteofbro }\end{array}$ & $\begin{array}{l}\text { Beef } \\
\text { Seminal } \\
\text { Vesicle }\end{array}$ & $\begin{array}{l}\text { Mouse } \\
\text { Macrophage }\end{array}$ & $\begin{array}{l}\text { Human } \\
\text { Leukocytes }\end{array}$ \\
\hline 1 & 4.19 & 3.94 & -.- & -- & -- \\
\hline 2 & 3.50 & --. & --. & 7.48 & 1.15 \\
\hline 3 & 2.91 & -- & 3.26 & -- & 5.83 \\
\hline 7 & --- & --. & 1.85 & -.. & --- \\
\hline 8 & 2.55 & 6.77 & 2.43 & 8.76 & 1.53 \\
\hline 9 & 2.51 & -- & 1.92 & -- & -- \\
\hline 12 & 3.53 & 5.49 & 7.60 & 9.80 & 4.77 \\
\hline 15 & 2.81 & 4.24 & 2.86 & 6.61 & 5.37 \\
\hline 16 & 2.41 & -- & 2.98 & -- & 5.37 \\
\hline 23 & 5.19 & 8.05 & -- & 6.59 & 2.80 \\
\hline 33 & 5.92 & 5.58 & -- & 9.89 & 3.47 \\
\hline 34 & 5.88 & 4.26 & 5.90 & 8.07 & 6.43 \\
\hline 36 & -- & -. & 2.23 & 6.67 & 5.67 \\
\hline 40 & 3.05 & 9.29 & $\cdots$ & 8.80 & 3.28 \\
\hline 46 & 6.59 & 2.33 & 0.71 & -- & 6.39 \\
\hline 57 & -- & $\ldots$ & 3.09 & -- & -- \\
\hline 74 & -. & -- & 1.52 & 6.31 & 4.06 \\
\hline 75 & 6.61 & 3.68 & 4.31 & -- & --. \\
\hline 76 & 1.61 & -- & 1.30 & --. & --- \\
\hline 77 & 7.72 & 1.09 & 1.39 & -.. & -.- \\
\hline 78 & 1.47 & 3.41 & 2.37 & -.- & --. \\
\hline 95 & -.. & -..- & 2.20 & --. & ... \\
\hline
\end{tabular}




\section{REFERENCES}

1. I.H. Hall, C.O. Starnes, Jr., B.F. Spielvogel, P. Wisian-Neilson, M.K. Das, and L. Wojnowick. J. Pharm. Sci. 68, 685, (1979)

2. A. Sood, C.K. Sood, B.F. Spielvogel, and I.H. Hall. Eur. J. Med. Chem. 25, 301, (1990)

3. M.K. Das, P.K. Maiti, S. Roy, M. Mittakanti, K.W. Morse, and I.H. Hall. Arch. Pharm. 325, 267, (1992)

4. K.G. Rajendran, B.S. Burnham, S.Y. Chen, A. Sood, B.F. Spielvogel, B.R. Shaw, I.H. Hall. J. Pharm. Sci., in press.

5. B.F. Spielvogel, "Boron Chemistry 4," p. 119-129, R.W. Parry and G. Kodama Eds. Pergamon Press New York, 1980.

6. A. Sood, C.K. Sood, B.F. Spielvogel, I.H. Hall, O.T. Wong, M. Mittakanti, and K.W. Morse. Arch. Pharm. 324, 423, (1991)

7. B.F. Spielvogel, F. Harchelroad, Jr., and P. Wisian-Neilson. J. Inorg. Nucl. Chem. 41, 1223, (1979)

8. I.H. Hall, B.F. Spielvogel, A. Sood, F.U. Almed, and S. Jafri. J. Pharm. Sci. 76, 359, (1987)

9. M. Mittankanti and K.W. Morse. Inorg. Chem. 29, 554, (1990)

10. M.K. Das, P.K. Maitti, S. Roy, M. Mittakanti, K.W. Morse, and I.H. Hall, Arch. Pharm. 325, 267, 1992.

11. B.F. Spielvogel, F.U. Ahmed, and A.T. McPhail. Synthesis 833, (1986)

12. D.A. Ferkes, M.R.M.D. Charandabi, R. Livengood, K.W. Morse. Boron USA II, Reserach Triangle Park, NC 1990, p. 40.

13. B.F. Spielvogel, F.U. Ahmed, K.W. Morse, and A.T. McPhail. Inorg. Chem. 23, 1776, (1984)

14. A. Sood and B.F. Spielvogel. Main Group Metal Chem. 12, 143, (1989)

15. A.T. McPhail, K.D. Onan, B.F. Spielvogel, P. Wisian-Neilson. J. Chem. Res. (5) 205, $m$ 2601, (1978)

16. B.F. Spielvogel, A. Sood, K.W. Morse, D.T. Wong, and I.H. Hall. Die Pharmazie 46, 592, (1991)

17. I.H. Hall, M.K. Das, F. Harchelroad, Jr., P. Wisian-Neilson, A.T. McPhail, and B.F. Spielvogel. J. Pharm. Sci. 70, 339, (1981)

18. J.L. Peters, V.M. Norwood, III, and K.W. Morse. Inorg. Chem. 24, 3713, (1986)

19. M.K. Das and S. Roy. Synth. Reactions Inorg. Chem. 15, 53, (1985)

20. A. Sood, C.K. Sood, I.H. Hall, B.F. Spielvogel. Tetrahedron 47, 6915, (1991)

21. M.P. Kaushik, M.R.M.D. Charandabi, M.L. Ettel, T.J. Lofthouse, and K.W. Morse. Inorg. Chem. 28, 897, (1989)

22. M. Mittankanti, MRMD Charandabi, and K.W. Morse. Inorg. Chem. 29, 3218, (1990)

23. Morse, et. al. to be filled in later.

24. C.K. Sood, A. Sood, B.F. Spielvogel, J.A. Yousef, B. Burnham, and I.H. Hall. J. Pharm. Sci. 80, 1133, (1991)

25. P. Roszkowki, W.H. Rooks, A.J. Tomolonis, and L.M. Miller. J. Pharmacol. Exp. Ther. 179, 114, (1971)

26. C.A. Winter, E.A. Risley, and G.W. Nuss. Proc. Soc. Exp. Biol. Med. 111, 544, (1962)

L.C. Hendershot and J. Forsaith. J. Pharmacol. Exp. Ther. 125, 237, (1959)

27. I.H. Hall, J.E. Hull, M. Mohseni, and F. Sajadi. J. Pharm. Sci. 69, 1451, (1980)

28. L.F. Sancilio. Proc. Soc. Exp. Biol. and Med. 127, 597, (1968)

29. B.H. Waksman, C.M. Pearson, and J.T. Sharp. J. Immunol. 85, 403, (1960)

30. P.S. Chen, T.Y. Toribara, and H. Warner. Anal. Chem. 28, 1257, (1956)

31. A.B. Roy. Biochem. J. 53, 12, (1953)

32. I.H. Hall and G.L. Carlson. J. Med. Chem. 19, 1257, (1976)

33. W.D. Schleuning and H. Fritz. Methods Enzymol XLV, 330, (1976) 
34. J. Kleinerman, V. Ranga, J. Rynbrant, J.Sorenson, and J. Powers. Am. Rev. Respir. Dis. 121, 381, (1980)

35. C.L. Hu, G. Crombie, and C. Franzblau. Anal. Biochem. 88, 638, (1978)

36. T.E. Cawston and A.J. Barrett. Anal. Biochem. 99, 340, (1979)

37. R.V.. Tomlinson, R.V. Ringold, M.C. Qureshi, and E. Forchielli. Biochem. Biophy. Res. Comm. 46, 552, (1972)

38. M. Glatt, H. Kalin, K. Wagner, and K. Brune. Agents and Action 7, 321, (1977)

39. D.L. Flynn, T.R. Belliotti, A.M. Boctor, D.T. Connor, C.R. Kostlan, D.E. Nies, D.F. Ortwine, D.J. Schrier, and J.C. Sircar. J. Med. Chem. 34, 518, (1991).

40. D.L. Flynn, T. Capiris, W.J. Cetenko, D.T. Connor, R.D. Dyer, C.R. Kostlan, D.E. Nies, D.J. Schier, and J.C. Sirar. J. Med. Chem. 33, 2070, (1990)

41. I.H. Hall, R. Simlot, C.B. Oswald, A.R.K. Murthy, H. ElSourady, and J.M. Chapman, Jr. Acta. Pharm. Nord. 2, 387, (1990)

42. I.H. Hall, K.G. Rajendran, S.Y. Chem, O.T. Wong, A. Sood, and B.F. Spielvogel. Agents and Action, submitted.

Received: March 22, 1994 - Accepted: April 19, 1994 - Received in camera-ready format: August 1, 1994 